Mila Gadžić, Ph.D.

University of Mostar, Faculty of Economics, Mostar,

Bosnia\&Herzegovina

mila.gadzic@sve-mo.ba

\title{
EUROPEAN CHALLENGES AND PROSPECTS FOR BOSNIA AND HERZEGOVINA
}

\begin{abstract}
Bosnia and Herzegovina ( $B \& H)$ belongs to the group of countries of the Western Balkans, which has the status of potential candidate for EU membership. However, to achieve candidate status and full EU membership, it is necessary to carry out complex structural reforms that should ensure convergence towards EU countries, which will be a long and difficult process.

The aim of this paper is to point to the specificities of economic and political transformations in $\mathrm{BiH}$ in the context of economic changes occurring in the environment and which can significantly affect the EU accession process. This paper gives an overview of the basic economic features of $B \& H$, as well as projections on the movement of certain economic categories in the forthcoming period. An analysis of the position of $B \& H$ in the group of countries of the Western Balkans and the perspective of economic growth was conducted.
\end{abstract}

Keywords: $E U$ membership, integration, structural reforms, competitiveness, prospects.

JEL: P48, O52

\section{INTRODUCTION}

$\mathrm{B} \& \mathrm{H}$ is in a very important phase of acquiring candidate status in the EU accession process, which means that the government must return to the path of deep and painful structural reforms aimed at aligning the 
political, legal and economic systems in accordance with the system of the European Union. However, we are deeply aware that the road to acquiring the status of candidate country for EU membership will not be an easy because B\&H is very complex and inefficient state. That's why we all together need to give answers to questions that go through a demanding process of adjustment to the EU rules.

Bosnia and Herzegovina's accession process takes place in significantly different circumstances with respect to the new member states of the European Union. After the financial crisis and the change of political relations in the world and in Europe, the EU is now faced with considerably different problems that ultimately can affect the process of joining B\&H and the Western Balkan countries.

In the process of rapprochement with the EU economic system, $\mathrm{B} \& \mathrm{H}$ must implement the necessary reforms in the socio-economic and political spheres. Although macroeconomic indicators point to positive trends, the process of transformation of the economic and political system is slow, and there are various internal and external hazards that can endanger the EU accession process.

\section{EUROPE'S CHALLENGES THAT COULD INFUENCED THE PROSPECTS FOR BOSNIA AND HERZEGOVINA}

$\mathrm{B} \& \mathrm{H}$, as the other countries of South-East Europe ${ }^{1}$, operate within a very complex european and global environment. The European Union faces a large number of different issues that can not be unambiguously answered. As a result of the financial crisis, there is still a lack of economic growth. Although the most developed countries in Europe have recovered from recession, other less developed countries still suffer the recession, especially Italy, Spain, Portugal and Greece. Such an economic environment in the conditions of the growing competition of other countries on a global scale creates a perception of significantly different expectations in relation to the time of the emergence and the process of the large EU enlargement.

\footnotetext{
${ }^{1}$ The sixt countries of Sauth East Europe (West Balcan countries) are: Albania, Bosnia and Herzegovina, Kosovo, Macedonia, Montenegro and Serbia.
} 
In such conditions, there is growing skepticism towards the European integration project both in the EU and in potential members. Brexit and the UK release announcement from the EU gives a different look at the future of the EU and the continuation of integration processes. When this is accompanied by a very complex political situation, the wars in the Middle East, followed by the migration crisis, it is clear that the security situation in the EU is also changing, and changes must be made in politics with a view to preserving its security and economic prosperity. At this point, the biggest problem is how to manage an immigrant crisis, whereby it is important to provide public support to a common European policy that obviously responds negatively to the problems caused by the arrival of immigrants from the affected areas of Syria and North Africa. Under such conditions, secessionist ideas are strengthened in one part of Europe, particularly in Scotland, Catalonia and Northern Italy, strengthening political options in developed EU countries that are opposed to enlargement policies, advocating a greater degree of independence within the EU or leaving the EU.

In such circumstances, the process of accession of $\mathrm{B} \& \mathrm{H}$ and other Western Balkan countries will depend on Europe's policy towards future wave of enlargement on the one hand and on the speed of reforms that potential candidate countries and candidate countries are ready to make.

On the other hand, for B\&H the European Union has no alternative, and it is necessary to accelerate the implementation of political and economic reforms, whose execution constitutes the necessary prerequisite for obtaining the status of a candidate country, and in the forthcoming phase and full membership in the EU. The basic benefits for $\mathrm{B} \& \mathrm{H}$ in the process of joining the European community can be summarized in several points:

- equal participation in the work of the Union and the creation of joint decisions and policies,

- the benefits of the internal market and the impact of the EU in international relations,

- cooperation in Development Projects (R\&D), EU funds intended for closing the gap and the like, 
- the protection of the country have in common security and defense policy,

- using the arrangement of the Union in international trade agreement (EU and WTO)

Real convergence criteria are the fundamental factor that will determine the speed of meeting the conditions for EU accession. Nominal convergence criteria do not reflect the need for sustainable real (structural) convergence between countries. It does not guarantee long-term economic growth of all Member States, nor the overall positive effects of the formation of the EU. Entering the weaker countries causes divergence compared to developed (Greece, Portugal). For real convergence are critical: export strategy, foreign direct investment (FDI), research and development and macroeconomic stability. Real convergence is process of catching up with the level of the EU average (convergence of income) and the completion of structural reforms.

The process of joining the $\mathrm{B} \& \mathrm{H}$ is the political interest of the European Union. The history of our region is nothing less than the history of European countries that are within the boundaries of the European Union. However, the process of political integration need to be compatible with the process of economic and social integration.

It is important, therefore, to take steps to $\mathrm{B} \& \mathrm{H}$ and other candidate countries to enable mutual economic, transport, energy and cultural ties as well as integration with the European Union.

In that sense, the most important investment priorities are:

- strengthening research, technological development and innovation, that means enhancing research and innovation (R\&I), infrastructure and capacities to develop R\&I excellence and promoting centres of competence, in particular those of European interest,

- promoting business and investment in innovation and research, and developing links and synergies between enterprises, R\&D centres and higher education, in particular product and service development, technology transfer, social innovation and public service applications, demand stimulation, networking, clusters 
and open innovation through smart specialisation supporting technological and applied research, pilot lines, early product validation actions, advanced manufacturing capabilities and first production in Key Enabling Technologies and diffusion of general purpose technologies.

Problems of the current development of B\&H can be observed through the weaknesses of "unconnected regions", while the advantages of integration into the European economic space can be observed through the" advantages of ,connected regions ". ${ }^{2}$

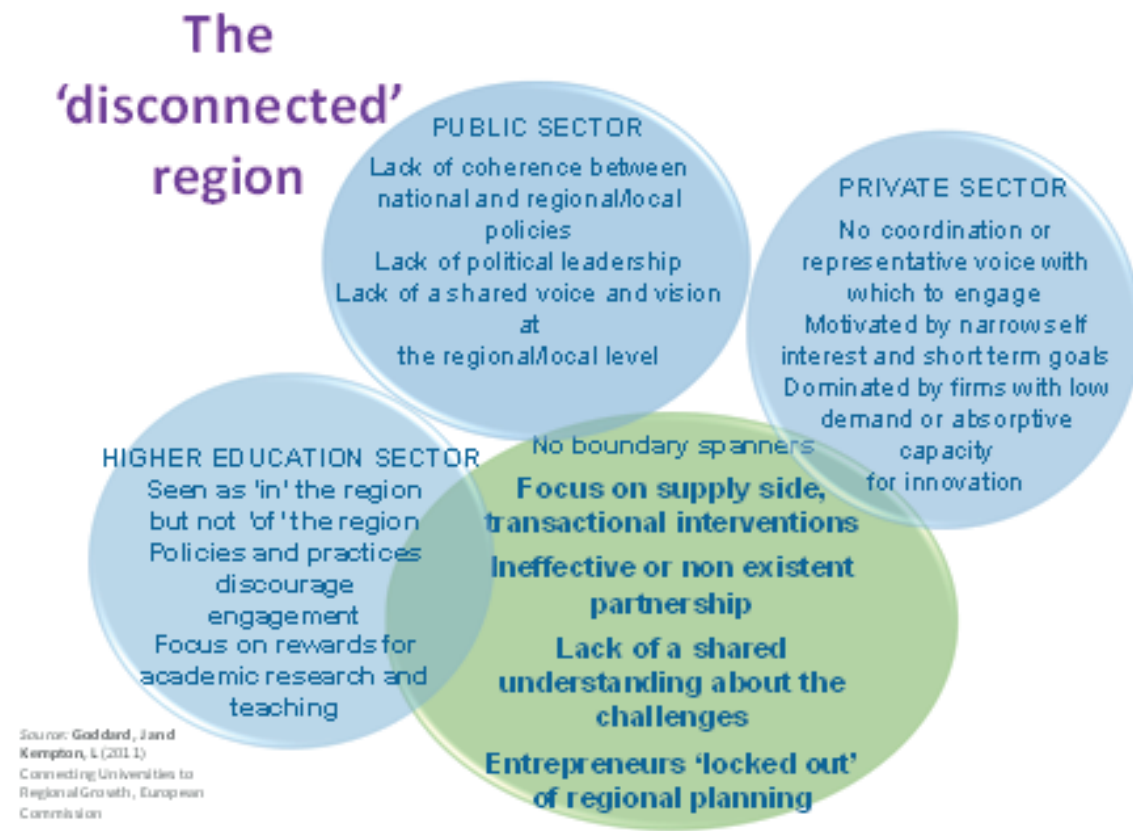

${ }^{2}$ Goddard, J., Kempton, L., (2011), Connecting Universities to Regional Growth, European Commission 


\section{The 'connected' region}

Strong partnerships based on shared understanding

of the barriers and how to overcome them

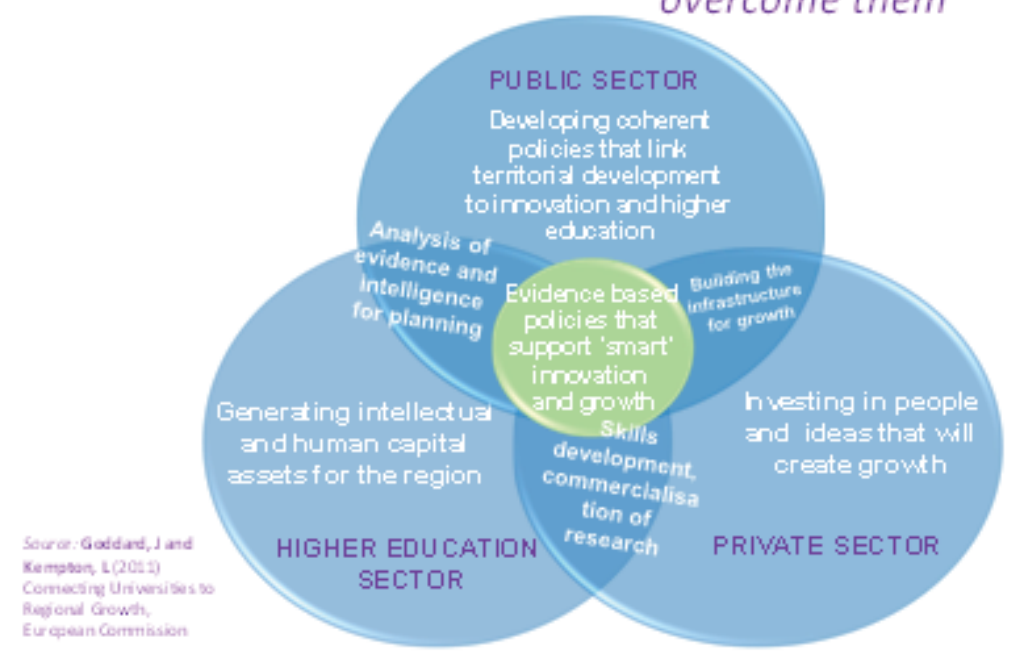

\section{BASIC CHARACTERISTICS OF THE B\&H ECONOMY DEVELOPMENT}

Reform Agenda for B\&H in the period from 2015-2018 is committed to $\mathrm{B} \& \mathrm{H}$ to be in a certain way with the improvement of the six areas, on the one hand, connected with the goals of the new approach 'EU' economic governance in the Western Balkans, on the other, that in accordance with the program of economic reforms maintain macroeconomic stability, and enhance growth and competitiveness. The reform agenda which should conduct $\mathrm{B} \& \mathrm{H}$, refers to six key areas:

1. public finance, taxation and fiscal sustainability,

2. the business climate and competitiveness,

3. the labor market,

4. the reform of social security and pension,

5. the rule of law and good governance,

6. public administration reform. 
The new IMF program helps carrying out the much-needed structural reforms and contains measures to strengthen the single economic space. B\&H will have access to a three-year, 608 million US\$ IMF loan under the Extended Fund Facility (EFF) to support a more competitive economy that can attract investment and create jobs in the private sector. Main goals of this program are: private sector growth, higher public investment, financial sector reform. Unemployment is running high, youth unemployment rate exceeds 62 percent. A large number of educated young people have left for Western Europe over the past two decades, further affecting the potential for future growth.

The state government economic program supported by the IMF has three main objectives:

First, enhance the business environment to attract investment:

- create private sector jobs and raise the economy's growth potential by carrying out labor market reforms to make the labor market more flexible,

- boosting the economy's potential by restructuring or selling large and inefficient state-owned enterprises,

- and lowering the distortive tax on formal sector employment, the labor tax wedge and reducing intra-country fragmentation by harmonizing tax laws among entities.

Second, improve the quality of government spending and make it progrowth by:

- lowering public employment and allowing the private sector to become an important player in the labor market,

- improving tax collection through better coordination among the tax authorities,

- spending more on infrastructure, health care, education, and investment,

- more focused targeting of social spending, including through pension reform,

- introducing fiscal and financial discipline in lower levels of government and state owned enterprises. 
Third, safeguard financial stability and revive bank lending by:

- preserving central bank independence and the currency board arrangement, which provides a fixed exchange rate anchor to policies,

- tackling vulnerable banks and improving the nonperforming loan recovery and resolution framework to revive bank lending,

- harmonizing banking legislations across the two entities,

- enhancing coordination and cooperation among the bank supervisory and regulatory agencies,

- lowering the fiscal risks from the operations of public development banks.

The IMF program, approved on September 7, 2016, enables further financial assistance from the World Bank, the European Union, and other international partners to help Bosnia and Herzegovina turn around its economy.

Catching up with advanced Europe requires extra effort. With the global economy less supportive in the medium term, lower growth can turn out to be the new normal in the region. This means that the pace of convergence to the living standards of advanced Europe may fall short of earlier aspirations. To close the gap with advanced Europe faster, B\&H thus need stronger policies to improve labor supply, boost investment, and increase efficiency. European Union through the strategic objectives (Europe 2020) put a smart, sustainable and inclusive growth at the center of its activities, with five main objectives (employment, research and development, climate change and energy, education and the fight against corruption).

Modern approach to economic growth and development search for answers the question of how to ensure a sustainable growth and better quality of life for all citizens. The general view of the answer lies in sustainable competitiveness that is focused on companies and industries rather than the economy as a whole. 
The competitiveness of the economy implies a sustained growth in productivity and business, that affect the macroeconomic and microeconomic policies, the business environment. Level of competition determines the productivity. Trerefore, the state must take measures to increase the overall social productivity. However, to develop a competitive advantage is not easy. Competitiveness requires a strategy based on knowledge, a thorough knowledge of consumer behavior, cooperation and rivalry among firms, external orientation and positive partnership between the government and the private sector.

The basis of competitiveness is in the nature of the environment in which businesses operate, which means that the business environment should be incentive to investing, transparent and efficient in providing the necessary information, the natural and human resources, physical infrastructure, financial resources, research, information and technology infrastructure.

The ability of firms to achieve competitive advantage depends not only on their strategy, innovation and jobs, but also from external factors and institutions. Macroeconomic reforms are necessary but not sufficient condition for the increase of social productivity and competitiveness. Microeconomic reforms are also essential, and they occur at the level of enterprises.

That is why the joint action of government and business is important to create an environment for competitiveness. The process of improving the competitiveness of $\mathrm{B} \& \mathrm{H}$ involves a partnership of governments, business and academic communities, all must work together on the challenges of the European and the global market place posed to country.

SMEs and their development have been incorporated into most EU policies and programs. The European Commission has undertaken several initiatives to promote entrepreneurship and SME development, such as the European Charter for Small Enterprises and the Entrepreneurship Action Plan. Implementation of European Charter for Small Enterprises is an essential part of the Lisbon strategy. Other important activities related to determining the comparative guidelines 
and share good practice. Time Europe's plans are designed for enterprise and SME for the next year, and they serve as a basis for SMEs Development Strategy in $\mathrm{BiH}$.

The main sources of growth of the private sector are in stimulating business environment, support the development of entrepreneurship and attracting foreign investment. In Bosnia and Herzegovina there has been a noticeable improvement in the removal of administrative barriers to domestic and foreign investment. However, strengthening entrepreneurship has been established as a prerequisite for faster development of the private sector, especially for SMEs growth.

The basis of competitiveness lies in the nature of the environment in which businesses operate, which means that the business environment should be supportive of investing, be transparent and efficient in providing the necessary information, natural and human resources, physical infrastructure, financial resources, scientific, information and technological infrastructure.

The following table shows unemployment rates in B \& $\mathrm{H}$ and selected EU countries. The problem of high unemployment of B \& H can only be solved if it is researching the implementation of the necessary reforms, which ultimately should lead to convergence of the economy towards EU economies. Unemployment indicators are different due to different approaches to unemployment records in B \& H. According to the Labor Force Survey, the number of unemployed in $\mathrm{BiH}$ in 2015 is 315 thousand, while there is a significant number of unemployed (675 thousand unemployed persons) according to the administrative number registered in the employment bureaus.

Table 1. Unemployment rate in B\&H and some countries in EU

\begin{tabular}{l|l|l|l|l|l|l|l|l|l}
\hline & B\&H & EU 28 & $\begin{array}{l}\text { Eurozon } \\
\text { e }\end{array}$ & Denmark & Germany & Croatia & Austria & $\begin{array}{l}\text { Sloveni } \\
\text { ăweden }\end{array}$ & \\
\hline $12 / 2015$ & $27,7 \%$ & $9,0 \%$ & $10,4 \%$ & $6,0 \%$ & $4,5 \%$ & $16,5 \%$ & $5,8 \%$ & $8,8 \%$ & $7,2 \%$ \\
\hline $12 / 201427,5 \%$ & $9,9 \%$ & $11,4 \%$ & $6,2 \%$ & $4,9 \%$ & $17,7 \%$ & $5,6 \%$ & $9,3 \%$ & $7,5 \%$ \\
\hline
\end{tabular}

Source: Central Bank of B\&H, 2016.

According to the Central Bank of B\&H estimates, the nominal gross domestic product (GDP) in 2015 is BAM 28,148 billion, which 
represents a growth of $3.26 \%$ compared to 2014 . With the assumed GDP Delayer (4.47\%) for 2015, real GDP has been estimated at BAM 26.943 billion $(+2.77 \%$ over the previous year).

Figure 1. Annual changes in nominal and real GDP

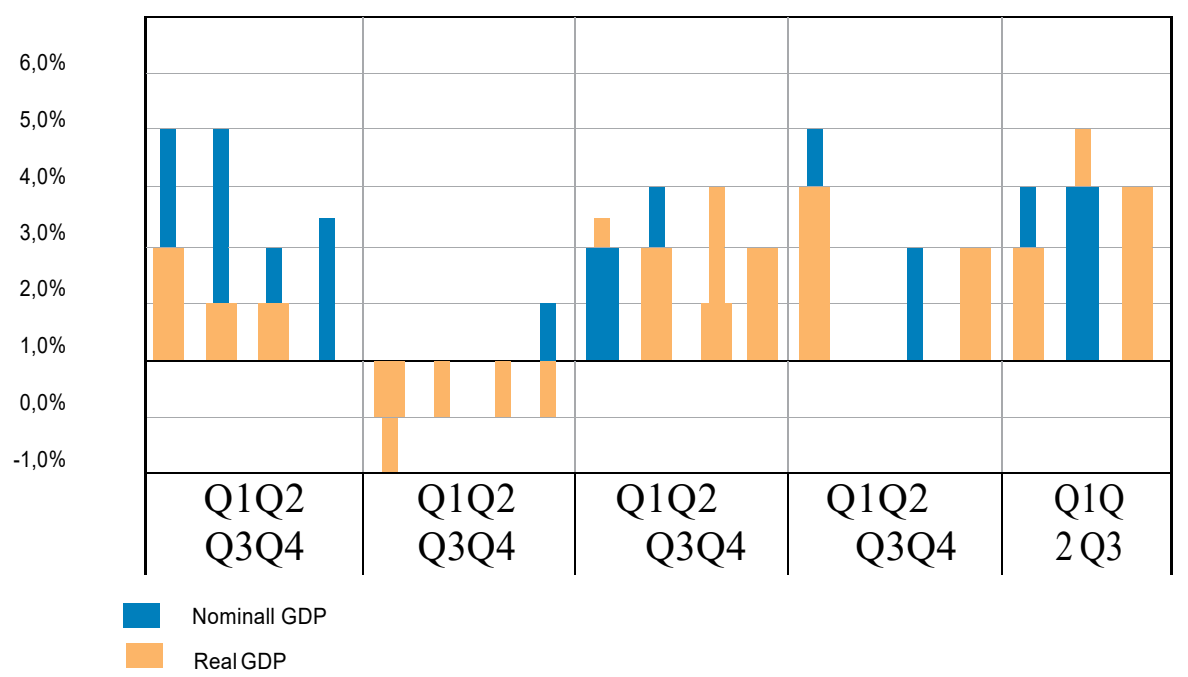

Source: Central bank of B\&H, Annual Report for 2015, 2016.

\subsection{The balance of payments position of $B \& H$}

The balance of payments position of B\&H in 2015 has improved. Current account deficit decreased by BAM 447.0 million or more than one quarter and amounted to BAM 1.59 billion. The biggest contribution to reducing the current account deficit is due to the increase in exports and decrease of imports, or decrease of trade deficit by BAM 653.0 million or $8.7 \%$, which ultimately positively affected the foreign exchange reserves. In 2015, total exports amounted to BAM 8.98 billion. In relation to the previous year, the value of exports increased by $3.5 \%$. Although annual export growth rates have been positive over the past five years, with the exception of 
2012, exports and stagnation growth slowed down over the past two years. $^{3}$

Figure 2. Balance of payments developments in $\mathrm{B} \& \mathrm{H}$ for the period 2014-2018

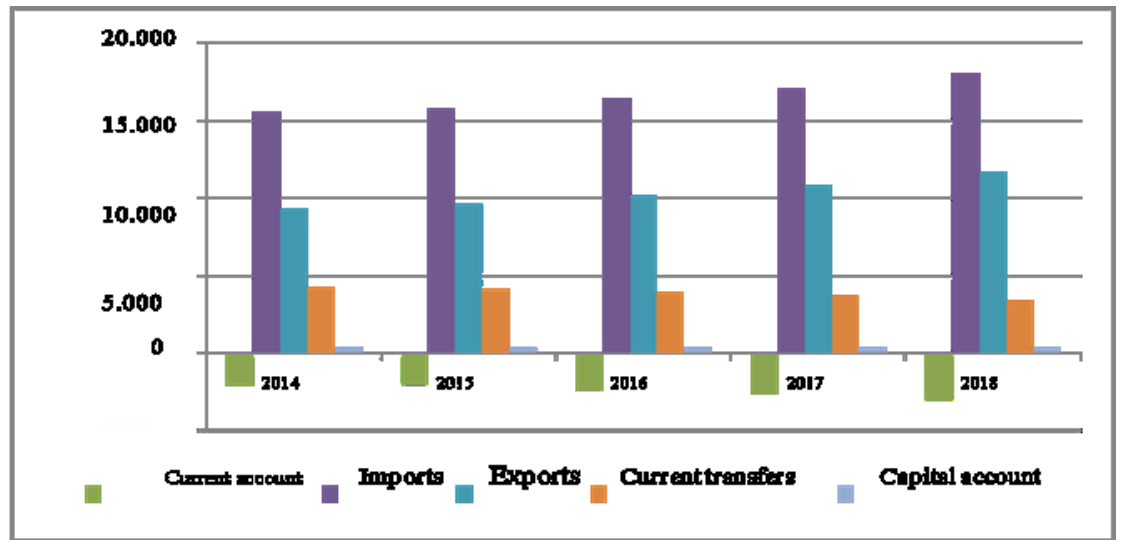

Source: Central bank of B\&H, Annual Report for 2015, 2016.

\subsection{Public indebtedness of $B \& H$}

In accordance with historical data and given projections, remains within the Maastricht Criteria B\&H still remains a moderately indebted country. Standard indicators of public debt sustainability show that public debt still does not pose threat to fiscal sustainability of $\mathrm{B} \& \mathrm{H}$ and the Entities. Since majority of public debt is allocated to the Entities and that domestic debt pertains exclusively to Entities, the text below shows the detailed overview of public (total) debt of Entities.

In 2015, governments at all levels in Bosnia and Herzegovina committed themselves to implementing fiscal consolidation. According to the Economic Reform Program for the period 2016 2018, primary deficit is projected at $0.4 \%$ of GDP for 2015, while its further reduction in the coming years is projected. These projections will pose a major challenge for $\mathrm{BiH}$ authorities at all levels, especially considering additional items of fiscal consolidation (in the Republic of

${ }^{3}$ Central bank of B\&H, Annual Report for 2015, 2016, p. 32. 
Srpska, pension funding will be made directly from the budget), which will represent a large budgetary burden.

Although within the Reform Agenda it is agreed to reduce B\&H's public debt relative to the gross domestic product, it still has a growing trend in GDP as both external and internal debt. The external debt of the general government sector at the end of 2015 was BAM 8,69 billion, which was up by BAM 248.9 million (2.9\%) compared to the previous year ${ }^{4}$. The following table shows public debt and projection for next period.

Table: 2. State of public debt and projections (in million KM)

\begin{tabular}{|l|r|r|r|r|r|}
\hline & \multicolumn{1}{|c|}{$\mathbf{2 0 1 4 .}$} & \multicolumn{1}{|c|}{$\mathbf{2 0 1 5}}$. & \multicolumn{1}{|c|}{$\mathbf{2 0 1 6 .}$} & \multicolumn{1}{|c|}{$\mathbf{2 0 1 7 .}$} & \multicolumn{1}{|c|}{$\mathbf{2 0 1 8 .}$} \\
\hline Foreign debt & 508.9 & 381.5 & 385.6 & 536.2 & 525.8 \\
\hline Domestic debt & 368.4 & 515.7 & 590.2 & 546.0 & 562.6 \\
\hline Total Federation B\&H & $\mathbf{8 7 7 . 3}$ & $\mathbf{8 9 7 . 2}$ & $\mathbf{9 7 5 . 8}$ & $\mathbf{1 , 0 8 2 . 2}$ & $\mathbf{1 , 0 8 8 . 4}$ \\
\hline Foreign debt & 265.0 & 219.8 & 275.0 & 364.2 & 376.6 \\
\hline Domestic debt & 352.4 & 397.0 & 517.7 & 506.0 & 593.4 \\
\hline Total Republic Srpska & $\mathbf{6 1 7 . 4}$ & $\mathbf{6 1 6 . 8}$ & $\mathbf{7 9 2 . 7}$ & $\mathbf{8 7 0 . 2}$ & $\mathbf{9 7 0 . 0}$ \\
\hline Foreign debt & 1.5 & 2.9 & 4.5 & 7.3 & 8.7 \\
\hline Domestic debt & 13.2 & 14.0 & 5.9 & 0.7 & 0.7 \\
\hline Total Debt B\&H & $\mathbf{1 4 . 7}$ & $\mathbf{1 6 . 9}$ & $\mathbf{1 0 . 4}$ & $\mathbf{8 . 0}$ & $\mathbf{9 . 4}$ \\
\hline $\begin{array}{l}\text { Foreign debt of } \\
\text { the Institutions of } \\
\text { B\&H }\end{array}$ & $\mathbf{4 . 1}$ & $\mathbf{4 . 1}$ & $\mathbf{4 . 6}$ & $\mathbf{4 . 4}$ & $\mathbf{4 . 4}$ \\
\hline TOTAL B\&H & & & & & \\
\hline Foreign debt & $\mathbf{1 , 5 1 3 . 5}$ & $\mathbf{1 5 3 5 . 0}$ & $\mathbf{1 , 7 8 3 . 5}$ & $\mathbf{1 , 9 6 4 . 8}$ & $\mathbf{2 , 0 7 2 . 2}$ \\
\hline Domestic debt & 779.5 & 608.3 & 669.7 & 912.1 & 915.5 \\
\hline $\begin{array}{l}\text { Debt repayment/GDP } \\
\text { (\%) }\end{array}$ & $\mathbf{5 . 4}$ & 926.7 & $1,113.8$ & $1,052.7$ & $1,156.7$ \\
\hline
\end{tabular}

Source: The Council of Ministers of B\&H, DEP

${ }^{4}$ Op.cit. p. 23. 


\section{PERSPECTIVES OF ECONOMIC DEVELOPMENT OF BOSNIA AND HERZEGOVINA AND THE COUNTRIES OF THE WESTERN BALKANS}

The long-term and sustainable development of Bosnia and Herzegovina depends to a large extent on the success of the entry into the Western European market because the country is heavily dependent on exports, especially in European Union countries. The low efficiency of the economy of Bosnia and Herzegovina is a natural brew of successful expansion on the Western European market. That is why building up national competitive advantages is the only way to overcome this obstacle; the growth of the competitiveness of local businesses creates the preconditions for entering the European and world markets.

A particular social and economic problem in the country is high unemployment, especially youth. The underlying causes of current unemployment are related to macroeconomic and structural imbalances and resource constraints. Integration of the economy into the EU creates conditions for the internationalization of economic activities and the arrival of foreign investors, which, with the establishment of new enterprises or by taking local ones, significantly affect the quality and volume of employment as well as the growth of competitiveness of the economy at the international level. Therefore, these processes and the labor market gradually adapt and integrate into the world.

Therefore, there is a realistic expectation that with the rise of FDI in $\mathrm{B} \& \mathrm{H}$, as well as in the Western Balkans (SEE6), growth will increase with the establishment of new companies. In times of economic recession and inadequate domestic financial resources, foreign equity in principle represents a major advantage for countries in transition. At the beginning of the process, FDI was expected to play a key role in the sustainable economic growth of these countries. Although total capital inflows have been achieved, it is still modest compared to expectations, mainly due to the deteriorating effects of macroeconomic instability and insufficient institutional reforms. As a result of such processes, there is not a sufficient level of 
competitiveness of the Western Balkans economies, which makes them less attractive for foreign investments.

\subsection{Competitiveness of Western Balcan economics}

The state of competitiveness of Western Balkan economies, according to research conducted by the World Economic Forum, is bad: these countries are among the least competitive countries, and the main factors that make this state of competitiveness compete are: infrastructure, financial market, systemic and institutional conditions, level of technological sophistication, Quality of production processes. This assessment shows that much more needs to be done to reach the average level of competitiveness in the near environment. A satisfactory level of country competitiveness is one of the conditions to be met for EU membership. Capacity needs to be built that will enable Western Balkan countries to face competition and the European Union market, which is a critical component of Copenhagen's economic criteria for EU accession.

In the context of economic development theory, the Global Competitiveness Index (GCI) assumes that the development of the economy in the first stage is dominated by factor-driven economies and their competitiveness is based on available factors, mainly on cheap labor and natural resources. Competition takes place on a pricebased basis, and low productivity is reflected in low wages. Maintaining competitiveness is mainly based on good public and private institutions, well-developed infrastructure, a stable macroeconomic environment and a healthy workforce that has attained the least elementary education. 
Figure 3. Structure of the Global Competitiveness Index

GLOBAL COMPETITIVENESS INDEX

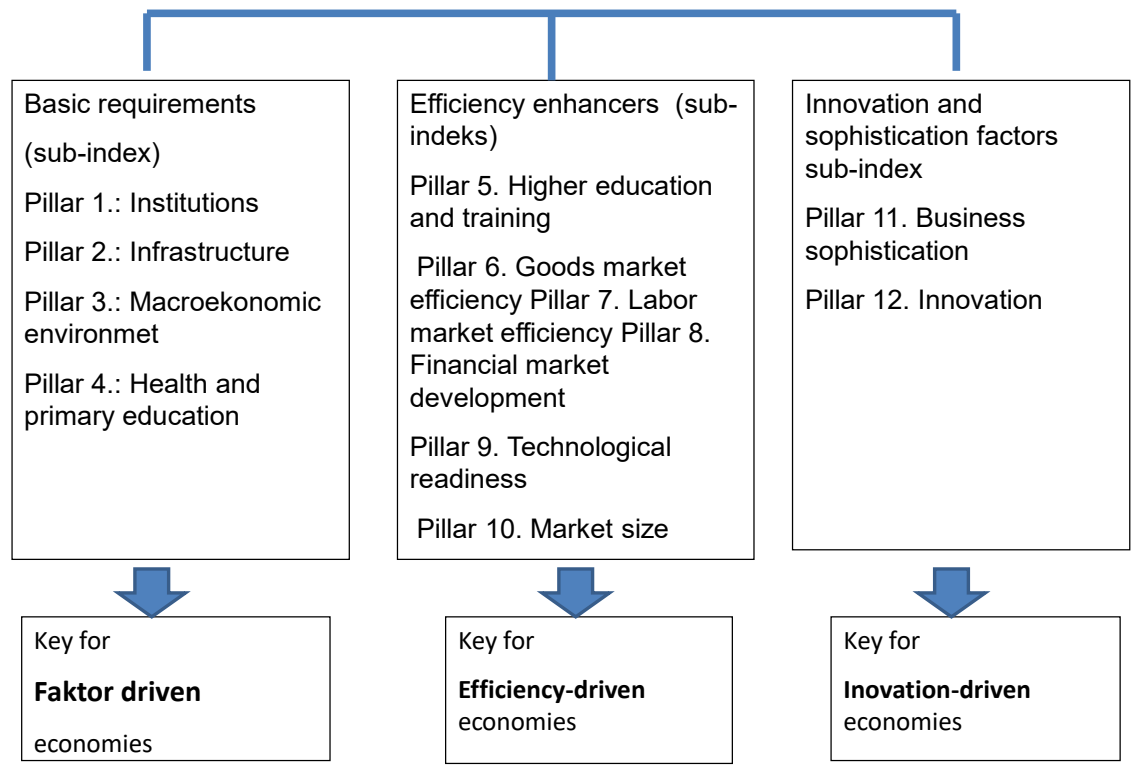

Source: The Global Competitiveness Report 2012-2013. World Economic Forum, Geneva, 2012., p. 8.

As country competitiveness improves, productivity grows and wages rise, and the country enters a growth-driven economy called "efficiency-driven economy", where more efficient production processes and product quality are developed. At this stage of development, growth in competitiveness is significantly affected by more education and training, an efficient commodity market, a welldeveloped labor market, a developed financial market, technology and a large domestic or foreign market.

As the country enters the third, innovation-led phase of economic development, companies compete with the production of new and different goods through new technologies and / or sophisticated manufacturing processes.

However, the relative importance of some pillars of competitiveness for each country depends on the stage reached in the development of its economy. Therefore, the pillars are organized into three sub-indices, each 
of which is crucial for a special phase of development. The sub-index of basic requirements groups the pillars that are determining for the first phase of development, the efficiency index sub-index grouping the columns that are determining factors at the development stage that is labeled as a driven economy, while the subindex of innovation and sophisticated factors includes the key columns For the country in the phase of economic development, which is marked by innovations driven by development. The countries that are between the two phases are marked by transition countries. Classification of countries according to development phases is given in the table 3 .

Table 3. Classification of countries by stages of economic development

\begin{tabular}{|l|c|c|l|l|l|}
\hline & $\begin{array}{l}\text { Phase } \\
1 .(\text { faktor- } \\
\text { driven) }\end{array}$ & $\begin{array}{l}\text { Transition } \\
\text { from Phase } \\
1 \text { to Phase 2. }\end{array}$ & $\begin{array}{l}\text { Phase 2. } \\
\text { (efficiency- } \\
\text { driven) }\end{array}$ & $\begin{array}{l}\text { Transition } \\
\text { from Phase } \\
2 . \quad \text { to Phase } \\
3 .\end{array}$ & $\begin{array}{l}\text { Phase } \\
\text { 3(Inovation- } \\
\text { driven) }\end{array}$ \\
\hline GDP p.c US\$ & $<2000$ & $\begin{array}{c}2.000- \\
2.999\end{array}$ & $3.000-8.999$ & $\begin{array}{l}9.000- \\
17.000\end{array}$ & $>17.000$ \\
\hline $\begin{array}{l}\text { The subindex of } \\
\text { basic } \\
\text { requirements }\end{array}$ & $60 \%$ & $40-60 \%$ & $40 \%$ & $20-40 \%$ & $20 \%$ \\
\hline $\begin{array}{l}\text { The sub-index } \\
\text { of efficiency } \\
\text { gains }\end{array}$ & $35 \%$ & $35-50 \%$ & $50 \%$ & $50 \%$ & $50 \%$ \\
\hline $\begin{array}{l}\text { The subindex } \\
\text { innovation and } \\
\text { sophistication }\end{array}$ & $5 \%$ & $5-10 \%$ & $10 \%$ & $10-30 \%$ & $30 \%$ \\
\hline
\end{tabular}

Sources: Source: The Global Competitiveness Report, 2015-2016. 2016-2017, World Economic Forum, Geneva, 2015., 2016.

According to the indicators of the Global Competitiveness Index, Bosnia and Herzegovina, as well as the countries of the Western Balkans, are in the phase of economic development that is driven by efficiency. At this stage of development, the country shows the need for investment, which will provide access to other markets, innovation and good business practices. In such a context, the side of a highly productive and competitive company can increase production efficiency and employment, know-how and technological advancement, which contributes to productivity growth, export orientation and competitiveness of the countries to come 
According to the World Economic Forum (2016/2017). Out of 140 countries, Bosnia and Herzegovina is rated at 107, while in the Report for 2012-2013. Was ranked 88th out of a total of 144 countries. Low weaknesses are low technological capability and innovation, state bureaucracy, inadequate policies and corruption.

Table 4. GCI-The rank of the Western Balkan countries towards the total number of ranked countries

\begin{tabular}{|l|l|l|l|l|l|}
\hline & $\begin{array}{l}2012-2013 . \\
(144)\end{array}$ & $\begin{array}{l}2013-2014 . \\
(148)\end{array}$ & $\begin{array}{l}2014-2015 . \\
(144)\end{array}$ & $\begin{array}{l}2015-2016 . \\
(138)\end{array}$ & $\begin{array}{l}2016-2017 . \\
(140)\end{array}$ \\
\hline Albania & 89 & 95 & 97 & 93 & 80 \\
\hline B\&H & 88 & 87 & - & 111 & 107 \\
\hline Montenegro & 72 & 67 & 67 & 70 & 82 \\
\hline Hrvatska* & 81 & 75 & 77 & 77 & 74 \\
\hline Macedoniaa & 80 & 73 & 63 & 60 & 68 \\
\hline Serbia & 95 & 101 & 94 & 94 & 90 \\
\hline
\end{tabular}

Source: The Global Competitiveness Report, 2015-2016. 2016-2017, World Economic Forum, Geneva, 2015., 2016.

The structure of the total GCI index is of different importance for each subindex. Table 5. shows the ranking of individual sub-indices in the group of Western Balkan countries.

Table 5. Ranking of countries according to the requirements of GCI for 2016.

\begin{tabular}{|l|r|r|l|l|}
\hline Country & GCI & $\begin{array}{l}\text { Subindex : Basic } \\
\text { requirements }\end{array}$ & $\begin{array}{l}\text { Subindex : } \\
\text { Efficiency } \\
\text { enhancers }\end{array}$ & $\begin{array}{l}\text { Subindex : Innovation } \\
\text { and sophistication } \\
\text { factors }\end{array}$ \\
\hline Albania & 80 & 74 & 86 & 106 \\
\hline $\begin{array}{l}\text { Bosnia and } \\
\text { Herzegovina }\end{array}$ & 107 & 94 & 106 & 122 \\
\hline Montenegro & 82 & 86 & 79 & 98 \\
\hline Croatia* & 74 & 68 & 68 & 92 \\
\hline Macedonia & 68 & 66 & 73 & 64 \\
\hline Srbija & 90 & 87 & 90 & 120 \\
\hline
\end{tabular}

Croatia joined the EU as a member of SEE6. In the table, we provided data for Croatia for comparison with Bosnia and Herzegovina and other SEE countries.

* Data for Kosovo are not reported.

Source: The Global Competitiveness Report, 2015-2016. 2016-2017.

World Economic Forum, Geneva, September, 2016. 
In the current phase of the efficiency of managed economic development, the most important pillars of competitiveness:

- more education and training,

- the efficiency of the commodity market,

- labor market efficiency,

- financial market improvement, technological readiness,

- the size of the market.

\subsection{Moderate economic development}

The movement of the basic macroeconomic indicators for this group of countries shows that, after recovery in 2010 and 2011, the countries re-enter the recession in 2012, when they had an average GDP decline of $-0.6 \%$. In the group of countries only Albania and Kosovo had a positive growth rate, while other countries had a recession. Idustrial production in the region declined by $3.6 \%$, except in Albania, which had a growth in production. However, the prospects for economic growth in this group of countries are positive, of course only assuming the planned structural reforms are achieved. Projections of positive outcomes as well as hazards that can determine the negative outcomes in this group of countries are given in tables 6 . and 7.

Table 6: Prospects for the economic growth of the countries of the Western Balkans

\begin{tabular}{|l|r|r|r|r|}
\hline & \multicolumn{1}{|c|}{2015.} & \multicolumn{1}{|c|}{$2016 .^{*}$} & \multicolumn{1}{|c|}{$2017^{*}$} & \multicolumn{1}{|c|}{$2018 .^{*}$} \\
\hline Albania & 2,8 & 3,2 & 3.5 & 3,5 \\
\hline B\&H & 3,0 & 2,8 & 3,2 & 3,7 \\
\hline Kosovo & 3,9 & 3,6 & 3,9 & 3.7 \\
\hline Macedonia & 3,7 & 2,0 & 3,3 & 3,7 \\
\hline Montenegro & 3,2 & 3,2 & 3.6 & 3,0 \\
\hline Serbia & 0,7 & 2,5 & 2,8 & 3,5 \\
\hline SEE6 & 2,2 & 2,7 & 3,2 & 3,6 \\
\hline
\end{tabular}

*Projection

Source: World Bank Group, South East Europe Regular Economic Report, No. 10, Resilient Growth And Rising Risks, 2016., p. 4. 
Table: 7. Tighter external outlook for the countries of the Western Balkans

\begin{tabular}{|l|r|r|r|r|}
\hline Percent of GDP & \multicolumn{1}{|c|}{2015.} & \multicolumn{1}{|c|}{$2016 .^{*}$} & \multicolumn{1}{|c|}{$2017 .^{*}$} & \multicolumn{1}{|c|}{$2018^{*}$} \\
\hline Goods exports & 25,3 & 25,7 & 26,7 & 26,9 \\
\hline Trade balance & $-15,6$ & $-15,2$ & $-15,1$ & $-15,2$ \\
\hline Current account balance & $-6,2$ & $-6,6$ & $-6,6$ & $-6,4$ \\
\hline Foreign direct investment & 6,0 & 4,7 & 4,8 & 4,8 \\
\hline External debt & 80,4 & 80,3 & 79,4 & 80,4 \\
\hline
\end{tabular}

*Projection

Source: World Bank Group, South East Europe Regular Economic Report, No. 10, Resilient Growth And Rising Risks, 2016, p. 10.

Prior to the outbreak of the global financial crisis, Bulgaria and Montenegro were the leading countries in the region to attract FDI, and in these countries the highest share of FDI in GDP was achieved: in Bulgaria, 29.7 in 2007 and in Greeks by $20.8 \%{ }^{5}$. After the outbreak of the financial crisis, the consequences of which have shifted to the real sector, there has been a decline in FDI, but they have risen again since 2009. The eurozone crisis negatively reflected the size of foreign investment, which resulted in slowing down the economy and deepening poverty and unemployment. Although the reasons for FDI decline are partly due to the reduction in investment activity of companies from countries that have suffered damage directly caused by the financial crisis, the second part of the reason for the fall in international investment may be sought in internal factors, in particular the lack of attractive investment environment, slow implementation of structural reforms, Deficiencies and bureaucratic barriers. The great interest of foreign investors at the beginning of the process, motivated by entering and gaining new markets, has weakened with growing uncertainty about the political and economic situation in the region. In addition, "national sentiment" has been shown in some countries by a factor that limits the influence of FDI in transformation processes, although it can generally be said that the Western Balkan countries have a positive attitude towards foreign direct investment.

\footnotetext{
${ }^{5}$ South East Europe: Regular Economic Report No.3. From Double-Deep
} Reccesssion to Accelerated Reforms, December, 18.22012., June 18.2013. 
The Western Balkan countries have the highest rates of unemployment and poverty in Europe. In addition, economic growth is weak and is largely not followed by an adequate increase in employment in the GDP growth periods. The average unemployment rate of SEE6 countries is about 22\%, which is more than twice as high as in Europe. Western Balkan countries are implementing structural reforms because the commitment of all countries towards Europe, which means convergence towards the European countries and a reduction in the size of GDP per capita. In order to achieve such longterm goals, it is necessary to carry out structural reforms that will result in the stimulation of trade, the financial flows and the reform of the labor market and the public sector. For the first three quarters of 2015, foreign direct investments in $\mathrm{B} \& \mathrm{H}$ economy are lower by $33.8 \%$ compared to the first three quarters of $2014 .^{6}$

Responsible for creating a more attractive environment for foreign investors as well as a healthy and competitive domestic sector, legal and institutional frameworks that encourage investment without discrimination, liberal foreign exchange system, flexible labor market, quality public sector.

EU countries are the most important trading partner of the SEE6 countries, and the strengthening of their chambers is a key factor in export and their economic growth. All countries are experiencing high current account deficits and have a fiscal deficit. As foreign investment is an important source of liquidity, investment and growth deficit financing, these are the key determinants of correcting macroeconomic imbalances and stimulating economic growth.

${ }^{6}$ Data of Central Bank of Bosnia and Herzegovina. 
Table 8.: Macroeconomic Indicators of SEE6 Countries in 2015

\begin{tabular}{|l|r|l|l|l|l|}
\hline Country & $\begin{array}{l}\text { Rate of } \\
\text { GDP }\end{array}$ & $\begin{array}{l}\text { Rate of } \\
\text { official } \\
\text { unemployment }\end{array}$ & $\begin{array}{l}\text { Budget } \\
\text { deficit (\% of } \\
\text { GDP) }\end{array}$ & $\begin{array}{l}\text { External Debt } \\
\text { \% of GDP) }\end{array}$ & $\begin{array}{l}\text { Balance of } \\
\text { current } \\
\text { account } \\
\text { (\%GDP) }\end{array}$ \\
\hline Albania & 2,8 & 17,1 & $-4,8$ & 74,2 & $-11,7$ \\
\hline B\&H & 3,0 & 27,7 & 0,7 & 76,6 & $-5,5$ \\
\hline Montenegro & 3,2 & 17,6 & -8 & 147,9 & $-13,4$ \\
\hline Kosovo & 3,9 & 32,9 & $-2,1$ & 33,4 & $-9,1$ \\
\hline Makedonia & 3,7 & 26,1 & $-3,6$ & 69,9 & $-1,4$ \\
\hline Serbia & 0,7 & 17,7 & $-3,7$ & 80,1 & $-4,8$ \\
\hline SEE 6 & 2,2 & 21,3 & $-3,6$ & 80,4 & $-6,2$ \\
\hline
\end{tabular}

Source: World Bank Group, South East Europe Regular Economic Report, No.10., Resilient Growth And Rising Risks, 2016.

For these countries, FDI is a very important factor in financing, exports and growth, although for sustainable long-term economic growth, sustainable financial adjustment and mobilization of domestic financial resources is a priority. However, in conditions where external risks are growing, countries need to turn to domestic sources of financing economic growth.

\section{CONCLUSION}

Bosnia and Herzegovina's accession process takes place in significantly different circumstances with respect to the new member states of the European Union. After the financial crisis and the change of political relations in the world and in Europe, the EU is now faced with considerably different problems that ultimately can affect the process of joining B\&H and the Western Balkan countries. According to the indicators of the Global Competitiveness Index, Bosnia and Herzegovina, as well as the countries of the Western Balkans, are in the phase of economic development that is driven by efficiency. At this stage of development, the country shows the need for investment, which will provide access to other markets, innovation and good business practices. For these countries, FDI is a very important factor in financing and sustainable financial adjustment and mobilization of domestic financial resources is a priority. 


\section{LITERATURE}

1. Annual Report for 2015. Central Bank of Bosnia and Herzegovina, 2016.

2. Bosnia and Herzegovina Economic reforme programme 20162018 (ERP BiH 2016-2018), Sarajevo, January 2016

3. Council of Ministers, Bosnia and Herzegovina Outlook 20152018, Spring 2015.

4. Global Investment Trends Monitor, No.11. , 23. January 2013.

5. Globalization and Development: an International business strategy approach, Transnational Corporations, Vol.15.No.1 2006.

6. Hansen, W. Michael, Theories of Transnational Corporations, Environment and Development, Copenhagen Business School, Institute for Intercultural ommunication and Menagement, 2010.

7. Icentives and Investments: Evidence and Policy Implications, Investment Climate Advisory Services of the World Bank Group, december 2009.

8. Investments Incentives, Growing use, uncertain benefits, uneven controls, An exploration of government measures to attract investments, GSI, 2007.

9. Redovni ekonomski Izvještaj za Jugoistočnu Europu, Povetry reduction and Economic Management Unit Europe and Central Asia Region, 2012.

10. South East Europe regular Economic Report, No.3. From Double-Dip Recession to Accelerated Reforms, December, 18.2012., Povetry Reduction and Economic management Unit Europe and Central Asia, The World Bank

11. South East Europe regular Economic Report, No.4. From Double-Dip Recession to Fragile Recovery, June 18. 2013., Povetry Reduction and Economic management Unit Europe and Central Asia, The World Bank 
12. South East Europe, Regular Economic Report, No.10. Resilient Growth And Rising Risks, Faall 2016. The World Bank

13. Strategic Framework for BiH, Council of Ministers, Sarajevo, August 2015.

14. The Global Competitiveness Report, 2012-2013., 2014-2015, 2015-2016. World Economic Forum, Geneva,

15. Transition Report 2012 Inegration Across Borders, EBRD 2012.

16. UNCTAD Training Manual on Statistics for FDI and the Operations of TNCs, Volume I, New York, Geneva, 2009.

17. World Investment Report 2012.; Towards a New Generation of Investment Policies, UNCTAD

18. World Investment Report 2015: Reforming International Investment Governance, UNCTAD

19. World Bank Group, Doing Business 2016, Measuring Regulatory Quality and Efficiency, Economic Profile 2016, Bosnia and Herzegovina, Flagship Report, 13th Edition

20. www. Europa.eu 